Pamiętnik Literacki 2016, 2, s. 179-197
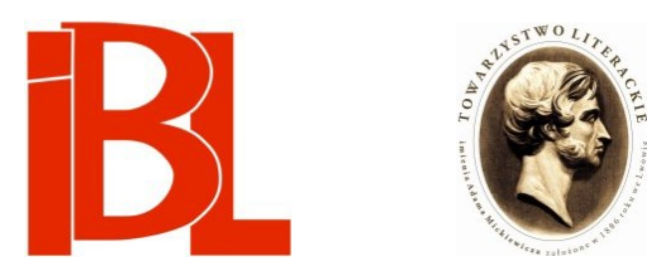

\title{
Kreatura - Świetlicki po pozorem męskości
}

\author{
Dawid Matuszek
}




\section{KREATURA - ŚWIETLICKI POD POZOREM MĘSKOŚCI*}

Mowę mi dałeś; cała $\mathrm{z}$ tego korzyść,

Że kląć dziś mogę; niech za to na ciebie Zaraza padnie, że mi dałeś mowę! ${ }^{1}$

\section{Kreatura}

W rozmowie przeprowadzonej przez Adama Wiedemanna w 1993 roku Wszyscy introwertyczni mężczyźni ida do wywiadu Marcin Świetlicki dokonał autoidentyfikacji, której przenikliwość do tej pory onieśmiela krytyków ${ }^{2} . Z$ właściwą sobie samowiedza zdefiniował - a patrzac z perspektywy czasu: zaprojektował - podmiot wypowiadający się w jego twórczości:

I ten, który mówi, to na pewno nie jest żaden Marcin Świetlicki, raczej „Marcin Świetlicki”, raczej jakaś wierszowa kreatura, ktoś oddychający powietrzem wiersza, jakaś przedziwna kukiełka. Bardzo bym chciał, żeby wszystkie reguły poetyczne nie odnosiły się do mojego pisania, może i dążę w tę stronę, ale - podkreślam - jeszcze d ą ż ę, nie osiąnąłem jeszcze tak doskonałej jedności z owym „Marcinem Świetlickim”, owym podmiotem, przedmiotem, pomiotem, kukiełka, Bohaterem Wierszy ${ }^{3}$.

„Wierszowa kreatura”, „przedziwna kukiełka”, „,Marcin Świetlicki»”. Od przytoczonego wywiadu upłynęło ponad 20 lat, wyszło wiele tomików poetyckich, kilka

* Praca naukowa finansowana ze środków Narodowego Centrum Nauki, realizowana została w ramach projektu Męskość w literaturze i kulturze polskiej od XIX wieku do współczesności. Projekt numer: DEC-2013/08/A/HS2/00058.

1 W. Szeks pir, Burza. W: Komedie. Wyd. 2. T. 1. Warszawa 1964, s. 163 (przeł. L. Ulrich). Dzieła dramatyczne. T. 1.

2 Takie onieśmielanie odbiorcy stanowi zresztą integralną część tego pisarskiego projektu. Lekturze Świetlickiego towarzyszy bowiem niepokojące poczucie, że każde potencjalne odczytanie zostało już przynajmniej na jakimś poziomie przez dany tekst uwzględnione. Tego rodzaju inkluzywność może przytłaczać, bo radykalnie ogranicza przestrzeń interpretacji. „Czytelność” Świetlickiego nie zaprasza wszak do uczestnictwa w niekończącym się procesie semiozy, tylko przeciwnie - udaremnia lub ośmiesza każdą próbę wejścia w ten proces: „Poetycki język Świetlickiego ustawiony jest na takiej częstotliwości, że wszelka próba krytycznej interpretacji narażona jest na niebezpieczeństwo popadnięcia w banał. Sam nie wiem, jaka jest tajemnica mechanizmu. [...] Sekwencje nieokreślonych, nieprawomocnych i nieortodoksyjnych zdań ani nie zestalają się w stwierdzenia pozytywne, ani nie odkrywają żadnej "zdolności negatywnej" [...], dzięki której moglibyśmy przełożyć wiersz na nasz własny język" (J. Gutorow, Dwa kroki w stronę ciemności, jeden do tyłu. Marcinowi Świetlickiemu na pięćdziesiąte urodziny. W: Księga zakładek. Wrocław 2011, s. 212-213).

3 Wszyscy introwertyczni mężczyźni idą do wywiadu. Z M. Świetlickim rozmawia A. W i e d e m a n n. „Czas Kultury” 1993, nr 6, s. 65. 
książek prozatorskich i parę nagranych płyt, ale podejście Świetlickiego do aktu twórczego nie zmieniło się: potrzeba suwerenności bez wiary w jej możliwość, żądanie autentyczności bez nadziei na jej zaistnienie. Władca marionetek tragicznie świadomy, iż sam jest tylko jedną z marionetek. Suweren, który wie, że konsekwentnie lokując się poza zbiorem („państwo”, „reguły”, „kanon”), zawsze stanowi jego część - jest nie-cały w ramach zbioru. To znaczy, podmiot jest jego nierozerwalną częścią, a zarazem (i w rezultacie) wykracza poza i w pewnym stopniu wpływa na rekonfigurację całego zbioru („tradycji”, ,jezzyka”...). Autor Schizmy zdaje sobie sprawę, że choć jego tron poetycki "góruje nad poddanymi i państwem”, to „status suwerena mieści się w granicach świata stworzenia”; że będąc panem stworzeń, „sam stworzeniem pozostaje”4 (,er ist der Herr der Kreaturen, aber er bleibt Kreatur"). Dlatego nie identyfikuje się z suwerenem, tylko z kreatura - stwórcą i stworzeniem w obrębie jednego podmiotu.

Benjaminowska koncepcja stworzenia (die Kreatur) została przez Świetlickiego mimochodem zmodyfikowana i zaktualizowana. Od łacińskiego czasownika „creare”, oznaczającego 'tworzyć', pochodzi wyraz „stworzenie” (łac. „creatura”), czyli - z jednej strony - kompletny „produkt” jakiegoś procesu twórczego, $z$ drugiej - określenie samego tego procesu. To zarazem gotowa kreacja i jej potencjalny dalszy ciag, możliwość przyszłej metamorfozy. Sens tego słowa obejmuje konkretne dzieło, ale także wszystkie jego ewentualne przekształcenia. „Stworzenie” nazywa zatem pewien okresowy stan zawieszenia - zawsze p o mi ę d zy ,już tak” a ,jeszcze nie”.

W języku polskim „kreatura” ma wydźwięk zdecydowanie negatywny i oznacza zazwyczaj człowieka nikczemnego, złoczyńcę, kogoś podłego, niegodziwego moralnie. Świetlicki wszakże, $z$ właściwą sobie dezynwoltura, przechwytuje ten termin i, nie rezygnując $z$ pejoratywnych implikacji, przywraca mu jego wymiar teologiczny ${ }^{5}$. Projektowaną przez autora Zimnych krajów kreaturę można by rozumieć jako materialistyczne, nieboskie stworzenie; odwrotność (albo wariację na temat) creatio ex nihilo. Moc stwórcza tej podmiotowości nie wynika jednak $\mathrm{z}$ ustanawiania nowej rzeczywistości literackiej, lecz z nieustannego „odswajania” tej zastanej, raz ustanowionej i wciąż ustanawianej przez coś albo przez kogoś innego. Choćby przez różne, mniej lub bardziej przychylne pisarzowi, wspólnoty czytelników.

Autokreacja, jaką tworzy on [tj. Marcin Świetlicki] w tekście, jest ściśle autotematyczna i tylko na zasadzie przyległości - w formie cytatu - poeta przywołuje obcy świat, który również został przez niego wykreowany, chociaż pozostaje wobec ,ja” manifestacyjnie oddzielony. Wypowiadając się o Świetlickim dostarczamy mu materiału, który on przetwar za na poetycki cytat - po awangardowemu czyniąc z życia sztukę. [...] W ten sposób Świetlicki zawłaszcza nas - i tak dramatycznie wydaje się przebiegać komunikowanie się w jego poezji ${ }^{6}$.

Awangardowość „Świetlickiego” nie polega na tym, że niszczy on tradycję i od-

4 W. B e n ja mi in, Źródło dramatu żałobnego w Niemczech. Przeł. A. Ko p a c ki. Posł. A. Li p s zy c. Warszawa 2013, s. 92.

5 Słowo „kreatura” w XVI wieku było używane w znaczeniu 'stworzenie boże, istota stworzona przez Boga (w sensie religijnym)', np. przez M. Reja (,onej slachetnej kreaturze, Aniołowi światłości”, cyt. za: A. B ań ko w s ki, Etymologiczny słownikjęzyka polskiego. T. 1. Warszawa 2000, s. 813).

6 J. Ors ka, Co robi z nami historia literatury? W: Liryczne narracje. Nowe tendencje $w$ poezji polskiej 1989-2006. Kraków 2006, s. 116. Podkreśl. D. M. 
rzuca wszystkie znane dotąd wzorce poetyckie, budując na ich gruzach coś z niczego, „całkiem od nowa”. Podstawa jego stwórczej pracy jest inna - „przetwarzanie” i przekształcanie dotychczasowego materiału tekstowego. Patologiczne przywiazanie do zastanej sytuacji zmienia się u Świetlickiego w pragnienie jej wypaczania. Jego bohater jest całkowicie w tej sytuacji zanurzony i przez nia w zupełności warunkowany, ale zarazem zawsze jakoś ją zniekształca, deformuje lub od-twarza. Konfrontacja $z$ twórczością autora Schizmy prowadzi do wniosku, że nie istnieje już właściwie żadna „zastana sytuacja”, że stale mamy do czynienia z jej zakrzywionym podwojeniem, $\mathrm{z}$ symulacja oryginału (bez oryginału).

Wierszowa kreatura to coś, co „porusza się pomiędzy”7. Oscyluje między tym, co jest (w miarę ustabilizowanym, uporządkowanym systemem), a tym, co nie-jest, czyli ,jest”, ale w zaprzeczeniu, zawieszeniu i w potencjalności równocześnie. Mam tu na myśli identyczny system, tylko odbity w krzywym zwierciadle ${ }^{8}$, przefiltrowany przez negujący, a mimo to twórczy grymas pisarza. Świetlicki zawsze przychodzi na gotowe. $Z$ jednej strony znajduje się więc stworzenie, pewien ład publiczno-prawny, zasady estetyczne i reguły języka, $z$ drugiej jednak pojawia się konieczność „potworzenia”, czyli natarczywej i nieusuwalnej ingerencji w ów ład, w zbiór zasad i reguł. Rodzi się potrzeba ich naruszania; Świetlicki pisze: „Jestem potworem na wakacjach” (Leżenie, $\mathrm{Cz} 297^{9}$ ), a na wakacjach mogę sobie na więcej pozwolić. Tym gestem ledwo zauważalnej, ale permanentnej deprawacji tekstowego świata kreatura Świetlickiego posługuje się jak orężem. Na przemoc Prawa odpowiada się tutaj przemoca kreacji. Nie w celu ustanowienia innej, mniej represyjnej postaci Prawa, lecz po to, by $z$ Prawem, którego istnienie uchodzi za niezbywalne (bo zawsze będzie jakaś jego forma), zlać się w jedną, rozszczelnioną całość. Aby uczynić je przez to mniej przejrzystym, mniej zdatnym do życia. Zepsuć je sobą, żeby uwierało.

Kreatura nie niesie nowych wartości (estetycznych, politycznych), tylko „odnawia” stare, sprawiając, że przestają one wydawać się akceptowalne. Odnawia, zakłócając. Dlatego w przypadku podmiotu Świetlickiego nie można mówić o „wierszowym stworzeniu”, bo to ostatnie jest kanoniczne i bywa pieszczotliwe („cóż to za piękne stworzenie?”), podczas gdy kreatura narodziła się z odstępstwa od kanonu, stanowi jego niekanoniczną odnogę, „podmiot, przedmiot, pomiot, kukiełkę” w jednym (,ty wstrętna kreaturo!”). Podmiot ten nie jest zatem kreatywny, tylko kreaturalny, a więc - jak pisze Władysław Kopaliński - „przedstawiający, uwydatniający w istocie ludzkiej to, co w niej podlega cierpieniom i troskom, co skazane na przemijanie, śmierć i rozkład"10. Podmiot kreaturalny nie kształtuje, lecz zniekształca. Poza tym uosabia zasadniczą słabość i cielesną wrażliwość, którą dzielimy z innymi istotami żywymi. Podmiot rozumiany jako kreatura to w gruncie rzeczy rezultat

$7 \quad$ Wszyscy introwertyczni mężczyźni idą do wywiadu, s. 66.

8 B enjamin (op. cit., s. 102) pisze: „Stworzenie jest zwierciadłem [...]. To krzywe zwierciadło”.

9 Utwory M. Świ etlicki e go - jeśli nie zaznaczono inaczej - przytaczam za wydaniem Wiersze (Kraków 2011), opatrując cytaty następującymi skrótami odsyłającymi do poszczególnych tomików: $\mathrm{Cz}=$ Czynny do odwołania; $\mathrm{N}=$ Niskie pobudki; $\mathrm{P}=$ Pieśni profana $; \mathrm{R}=$ Wiersze rozproszone; $\mathrm{T}=$ Trzecia połowa; $\mathrm{W}=37$ wierszy o wódce $i$ papierosach; $\mathrm{Z}=$ Zimne kraje. Cyfry po skrótach wskazują stronice w zbiorze Wiersze.

10 W. Ko paliń s ki, Słownik wyrazów obcych i zwrotów obcojęzycznych z almanachem. Warszawa 2007, s. 315. 
zapomnienia i zarazem przypomnienia o naszej zwierzęcej naturze, to figura ilustrująca zaprzeczenie, a także powrót zaprzeczonej przez człowieka zwierzęcości albo, po prostu, fizyczności (co wychodzi na jaw w chwilach, gdy traci się nad ciałem kontrolę, gdy ono zachowuje się, jak chce). To wreszcie podszyty pragnieniem popęd, „rzucajacy wyzwanie wszystkiemu, co istnieje”11.

Kreatura to byt naznaczony nieokreślonością; zamieszkując szczelinę między gatunkami, staje się zagrożeniem dla całego systemu klasyfikacji ${ }^{12}$. Ta liminalność, pojmowana jako stan „pomiędzy”, a także jako możliwość wyjścia poza codzienność, oderwania się od aktualnej sytuacji, zawieszenia wszystkich swoich dotychczasowych ról, powoduje, że kreatura lokuje się niewiarygodnie blisko wymiaru suwerenności, mimo że sama, tak jak wszelkie stworzenie, podlega woli suwerena - słowo kreatury nie gwarantuje jednak totalności i domknięcia systemu, lecz zapewnia jego radykalną otwartość. Kreatura nie uosabia wyjątku (który nie narusza Prawa, tylko je funduje), ale ustaloną wcześniej regułę, składającą się wszak wyłącznie z wyjątków. Przyznaje sobie wieczne prawo do zawieszania Prawa; jest strukturalną niespójnością, zarazem wewnątrz i na zewnątrz Prawa. Niczym kobieta - nie-cała, pas-toute - w wykładni różnicy seksualnej zaproponowanej przez Jacques'a Lacana (tutaj w interpretacji Kennetha Reinharda):

Inaczej niż w przypadku mężczyzn, którzy mieszczą się w domkniętej kategorii „wszystkich mężczyzn" i są rozpoznawani jako jej przedstawiciele, kobiety są radykalnie jednostkowe, nie sa przykładami klasy czy elementami domkniętego zbioru, tylko każda jest wyją tkiem. Sa jednak wyjątkiem nie od "reguły”, tylko od zbioru otwartego, nieskończonej serii poszczególnych kobiet, do której każda z nich wchodzi ,jedna po drugiej”. [...] Mężczyzna należy do podzbioru ludzkości zwanego „wszystkimi mężczyznami”, który go obejmuje i stanowi jednorodna grupę na mocy transcendentalnej wyjątkowości Ojca pierwotnego. Kobieta jednak należy do zbioru kobiet, nie będąc objętą zbiorem, jako że zbiór ten nie ma granic określających przynależność i oddzielających wnętrze od zewnętrza ${ }^{13}$.

Przekładając tę logikę na interesujące nas tu kategorie, można powiedzieć, że kreatura należy do zbioru „literatura”, nie będąc do końca objęta tym zbiorem, ale równocześnie znajdując się w nim bez wyjątku i w rezultacie ów zbiór rozdzierając. W tym sensie kreatura jest kobietą.

W obrębie tych prostych opozycji nie mieści się - a w konsekwencji je rozsadza - figura żywego trupa, który „w kategoriach życia i śmierci [...] jest n i e r o z s tr z ygalny"14. Zdaniem niektórych krytyków (m.in. Grzegorza Olszańskiego i Krzysztofa Hoffmanna), to właśnie nieumarły (zombie) mówi najwięcej w poezji Świetlickiego; mówi tak wiele, że śmierć zostaje w tym pisarstwie zagadana i traci cały swój nadzwyczajny charakter. Za dużo tu śmierci i umierania, a zatem -

J. La can, The Ethics of Psychoanalysis 1959-1960. Ed. J.-A. Miller. Transl. with notes by D. Port e r. New York - London 1992, s. 212. The Seminar of Jacques Lacan. T. 7.

12 Na ten temat, choć w innym kontekście, zob. M. A b b o t t, The Creature Before the Law: Notes on Walter Benjamin's „Critique of Violence”. „Colloquy. Text, Theory, Critique” 16 (2008).

13 K. Rein hard, W stronę politycznej teologii bliźniego. W: S. Žižek, E. L. Santner, K. Reinh a rd, Bliźni. Przeł. E. Ulińs ka. Posł. A. Bielik-Rob s on. Warszawa 2013, s. 79-80.

14 J. Collins, B. Mayblin, Derrida. Przeł. B. Umiń s ka. Warszawa 2000, s. 10. Cyt. za: G. O1s z a ń s ki, Trup, który mówi. W zb.: Mistrz świata. Szkice o twórczości Marcina Świetlickiego. Red. P. Śliwiński. Poznań 2011, s. 67. 
to, co można by potraktować jako eksces, jest czymś powtarzalnym - Świetlicki posługuje się tym motywem przede wszystkim jako metaforą nieprzystawalności jednostkowej wizji świata do otaczającej rzeczywistości i niezwykle wyrazistą figurą obcości. Główną stawką w tej grze nie jest wszak wcale śmierć fizyczna, lecz ta będąca efektem wyobcowania/wykluczenia z porządku symbolicznego ${ }^{15}$.

Stawką jest śmierć cywilna, symboliczna, związana z odmową przyjęcia dowodu osobistego albo $z$ odrzuceniem go:

Dzisiaj dostałem pismo od państwa.

Państwo chce, bym się zgłosił w stosownym urzędzie.

Państwo nie prosi, państwo żąda.

$[\ldots \ldots \ldots \ldots]$

Ale ja umarłem,

ja umarłem.

Nie chodziłem głosować

na urzędników państwa.

Sam sobie jestem winien.

[ . . . . . . . . . . . . .]

Czasami z przyzwyczajenia

golę się, lecz zarost

rośnie nawet umarłym.

$[\ldots \ldots \ldots \ldots \ldots]$

Czasami piszę wiersze

i wiem, że w ten sposób

sprawiam przykrość państwu.

Jeśli wezwanie to dotyczy

akurat tego faktu,

to nie zamierzam się tłumaczyć.

$[\ldots \ldots \ldots \ldots \ldots]$

Jeśli umarli mogą być

zagrożeniem dla państwa,

jeśli nie są bezkarni,

to tak widocznie musi być,

nie mogę umrzeć bardziej...

(K; Cz 348-349)

Wiersz nie ma jednak w tytule „Z” jak zombie, tylko „K” jak kreatura, którą był do pewnego stopnia także Józef K. („przeżyty” przez swój wstyd). Warto podkreślić, że Walter Benjamin w słynnym eseju o Franzu Kafce mianem „stworzenia” („die Kreatur”) nie nazywa K., tylko „pomocników”, „twory niegotowe” zaludniajace prozę pisarza z Pragi:

W indyjskich legendach pojawiaja się gandharwy, twory niegotowe, istoty w mglistym stadium bytu. Tacy właśnie są Kafkowscy pomocnicy; nie przynależą do żadnego kręgu stworzeń, w żadnym jednak nie są obcy: to posłańcy, którzy wędrują między nimi. [...] Nie wydobyli się jeszcze całkiem z matczynego łona natury [...]. To właśnie dla nich i im podobnych, dla istot niegotowych i niezdarnych, istnieje nadzieja ${ }^{16}$.

16 W. Benjamin, Franz Kafka. Z okazji dziesiątej rocznicy jego śmierci. W: Konstelacje. Wybór tekstów. Wstęp. A. Li p s zy c. Kraków 2012, s. 231-232 (przeł. A. Li p s zy c). 
Kreatura nigdzie nie przynależy, ale nigdzie nie jest obca, znajduje się pomiędzy - sposób, w jaki Benjamin opisuje swoje stworzenia (tu: „pomocników”), z powodzeniem można odnieść do kreatury Świetlickiego:

Żadna $\mathrm{z}$ nich [tj. istot, kreatur] nie ma ustalonego miejsca, swego ustalonego, niewymiennego konturu: nie ma takiej, która nie wznosiłaby się lub nie opadała; która nie zamieniałaby się miejscami ze swoim wrogiem czy bliźnim; która u kresu swych dni nie byłaby jeszcze niegotowa, która mimo głębokiego wyczerpania nie rozpoczynałaby dopiero długotrwałej egzystencji ${ }^{17}$.

Jeszcze niegotowa, wyczerpana, bez miejsca i konturów, ale „czynna”, taka jest podmiotowość K[reatury] Świetlickiego. Figura żywego trupa jest mniej operatywna o tyle, o ile całkowicie wyklucza logikę pragnienia i ogranicza czynność pisarską do ślepego przymusu. Kreatura to urzeczywistnienie gry między mechanicznym przymusem a pragnieniem („nie zamierzam się tłumaczyć”). Bez tego wyjątkowego zaczepienia w Prawie nigdy nie pojawiłaby się szansa na jego zmianę. Najkrócej rzecz ujmując: żywy trup nie powie o sobie, że jest żywym trupem. Zombie nie jest zwierzęciem politycznym, a kreatura - owszem.

W książce The Ethics of Psychoanalysis Jacques Lacan scharakteryzował rolę artysty jako zawsze i zasadniczo sprzeczną $z$ ideałami czasów, w których ów artysta działa. Pisał:

To przeciw temu, co bieżące, w opozycji do rządzących norm - włączając w to np. normy polityczne czy systemy myślenia - sztuka każdorazowo stara się dokonywać swoich cudów ${ }^{18}$.

Ten cud sztuki Lacan dostrzega w (nie)uświadomionej konieczności niezgadzania się z panującymi regułami i aktualnymi sposobami myślenia.

Kreatura Świetlickiego nie jest zatem konsekwentną lacanistką. Co prawda, „brejka wszystkie rule” (Brejkanie, Cz 282), ale nie w opozycji do bieżących norm, tylko - paradoksalnie - w zgodzie $z$ nimi. Łamie je na ich zasadach. Albo inaczej, lamie zasady za pomoca samych tych zasad:

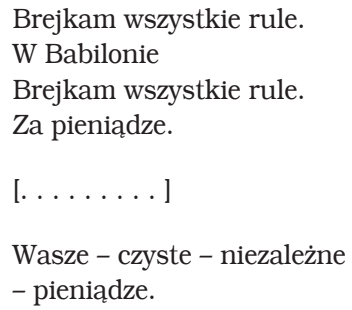

Kreatura zamieszkuje zniekształcone życie i tym samym je zniekształca; jest niczym garbusek i Mesjasz w jednej osobie, o której „pewien rabin powiedział, że nie chce wcale zmieniać świata przemoca, a jedynie go trochę poprawić" ${ }^{19}$. Mesjasz „Świetlickiego” nie wywodzi się wszakże $z$ judaizmu, lecz z chrześcijaństwa, więc 
pragnie ten świat nieco naruszyć, wygarbować mu patykiem skórę („Maleńki Jezus [...] / [...] / Wpadał z patykiem w dłoni między rówieśników / organizując rewolucje" 〈Apokryf, Z 13〉). I dlatego podmiot ów zawsze wydaje się idealnie skrojony na miarę tego świata, który ma zmieniać. Im bardziej do świata przystaje, im bardziej się z nim zlewa, tym mniej do niego pasuje (stąd wrażenie „czytelności” Świetlickiego, które zamienia się w interpretacyjna niemoc czy frazes). Nie chodzi bowiem o to, żeby buntować się przeciwko organizacji społecznej (język, państwo, rodzina, klasa, płeć), w której środek zostało się mimowolnie wrzuconym. Nie w tym rzecz, by ujawniać mroczną stronę, brudna podszewkę oficjalnego systemu. Nie idzie też o to, żeby w poetyckim uniesieniu demaskować fakt, że -

ta formacja społeczna, w której jesteśmy zanurzeni, sama jest pełna niespójności i niedokończeń, sama jest nawiedzona przez brak, przez który jesteśmy w jakiś dziwny sposób przyzywani, „podekscytowani” nim, za który jesteśmy w jakimś sensie odpowiedzialni ${ }^{20}$.

Świetlicki wszystko to wie (nawet jeśli jest to wiedza, o której nie wie): ten cielesny brak, ta (po lacanowsku rozumiana) k o b i e c o ś ć funduje cała jego twórczość; po co miałby jeszcze o tym pisać? To pisze się samo. I nieustannie drażni, ekscytuje:

on [tj. bohater Świetlickiego] za bardzo - jak na mój gust - wie, że jest w wierszu, że to jest wiersz. [...] Drażni mnie jego jakaś nadświadomość formy, gestu, postawy. I zachwyca ${ }^{21}$.

„Nadświadomość formy”, z którą taki problem ma Karol Maliszewski (ale też inni krytycy), to właśnie obecność w niej kobiecej kreatury, która znajduje sobie „miejsce na krawędzi tego świata, tak by korzystając $z$ jego konstrukcji, mogła dostrzec inny, alternatywny świat" 22 .

Jeśli zatem poprzez sublimację kształtuje się uznane społecznie wartości i hierarchie, to kreatura Świetlickiego dokonuje czegoś na kształt desublimacji, wykroczenia poza te wartości i hierarchie poprzez wygranie ich do końca, a także przez skonfrontowanie ich z nieznośną materialnością pisma. Pragnieniem poety jest nie tyle kreowanie nowych wartości, ile przeformułowywanie, „prze-twarzanie” starych. „Sublimacja pozwala poradzić sobie $z$ anonimowością, odbierającą mowę, umożliwia formowanie świata w tworzywie języka"23, ale zarazem odcieleśnia pismo. Przeciwnie desublimacja:

przypomina o istnieniu materialności, zmysłowości, cielesności, przemocy, głupoty, seksualności. Ten ruch od sublimacji, dążenia do tego, aby wykroić ze świata określone figury czy pewne obrazy, do desublimacji, która polega na oddaniu pola materialnemu i destrukcyjnemu popędowi, zdaje się napędzać całe pisanie poety ${ }^{24}$.

Kiedy Lacan wspomina o twórczej sublimacji (takiej, która może prowadzić do zbudowania nowego systemu wartości), zdecydowanie wiąże ją z popędem śmierci,

E. L. S a nt ner, Cuda się zdarzaja. Benjamin, Rosenzweig, Freud i problem bliźniego. W: Ži ž e k, Santner, Reinhard, op. cit., s. 115.

21 K. Maliszewski, Nasi klasycyści, nasi barbarzyńcy. Szkice o nowej poezji. Bydgoszcz 1999, s. 65.

22 T. Sław ek, Kobieta. „bruLion” nr 14/15 (1990), s. 126.

23 J. M o m r o, Świetlicki: plastyczność świata. W zb.: Mistrz świata, s. 248.

24 Ibidem. 
z cielesnością języka i językiem jako ciałem - ten afektywny element musi bowiem wykonać destrukcyjną brudną robotę, „zawiesić istniejący porządek Prawa, tym samym niejako posprzatać ze stołu i otworzyć przestrzeń dla sublimacji, która pozwoli zapoczątkować prace kreacji”25. Świetlickiego natomiast najbardziej interesuje to, co dzieje się „na stole”, dlatego jego kreatura nigdy nie opuszcza kanonicznej biesiady ${ }^{26}$. Nawet wtedy - albo tym bardziej wtedy - gdy „po wierszach / pozostaje smród" (Do Jana Polkowskiego, Z 61).

W tomie Jeden z 2013 roku figura wierszowej kreatury (,przedziwnej kukiełki”) zostaje ponownie, tym razem poetycko, zidentyfikowana:

\author{
Deska na klatce schodowej, która czasem płacze, \\ kwili jak jaki ptaszek, dziecko, kociak, jak \\ niebożę jakieś. \\ Wystarczy odpowiednio na niej stanąć, wydobywa się \\ $\mathrm{z}$ niej ten płacz podówczas, niczemu nie służy, \\ a jest. \\ Płacz wklęty w drewno, upiorny Pinokio, \\ który się nie urodzi, który tylko noca \\ usiłuje wyrazić się 27 .
}

Ten niesamowity wiersz jest niemal dosłownym przedstawieniem kreatury. Upiorny Pinokio, dziecko, nieboże stworzenie, kwili i jęczy, próbując wydobyć się $\mathrm{z}$ drewna na świat. Wyrwać się zatem ze swojej istoty, $\mathrm{z}$ materii, która go konstytuuje, a jednocześnie unieruchamia w bezkształcie. Słychać jęk i skowyt - tak formuje się materialny (a zarazem nie do końca materialny, bo upiorny) podmiot, tak brzmi cielesność języka („Płacz wklęty w drewno”), gdy nie chroni się ona pod parasolem symboliki. Nie da się twórczo wyrażać bez bólu. Stanem tego podmiotu jest więc nie tyle śmierć, ile permanentne nie-u-rodzenie się. Niewykluczone, że wiersz ten był chwilowa próbą egzorcyzmowania kreatury (w wersji muzycznej poeta deklaruje: „W tym domu / w którym już nie mieszkam”), ale coraz dłuższy nos Pinokia nie pozwala niczego stwierdzić na pewno.

Konsekwentna jest $z$ pewnością u Świetlickiego poetyka niwelowania czy wchłaniania sprzeczności. W wywiadzie cytowanym na początku niniejszego artykułu mówi on tak:

Siedzę w tych skrajnościach po uszy - jestem głaskany raczej przez krytykę, [...] a jednocześnie - nie jestem w żaden sposób związany z establishmentem literackim, bo i nie chcę, i mnie tam nie chca, dziwiłbym się, gdyby chcieli. W momencie kiedy poczułem, że głaszczą mnie za bardzo, że mają takiego

S. Žiž ek, Enjoyment within the Limits of Reason Alone. W: For They Know Not What They Do: Enjoyment as a Political Factor. London, N.Y., 2008, s. LXXXIII.

26 A. Ni ew i d o m ski (Jak 〈jednocześnie) być i nie być poeta należacym do kanonu? Przypadek Marcina Świetlickiego. Na stronie: http://portliteracki.pl/przystan/teksty/jak-jednoczesnie-byc-i-nie-byc-poeta-nalezacym-do-kanonu-przypadek-marcina-swietlickiego, data dostępu: 10 IV 2016) twierdzi np.: „Wydaje się, że najważniejszym zagadnieniem tej poezji nie są kwestie egzystencjalne, lecz retoryka stosunku do kanonu [...]".

27 M. Świetlicki, Czarne tygodnie. W: Jeden. Kraków 2013, s. 12. W wersji muzycznej zamieszczonej na płycie Świetlików Sromota (2013) tekst utworu jest nieco inny. 
modelowego oswojonego kontestatora, co niby zbuntowany, a pisze ladniutkie wiersze - zacząem występować z muzykami [...]. Powoli w oczach i jednych, i drugich staję się czymś w rodzaju zarozumiałego sukinsyna, to mi odpowiada, muszę doprowadzić do takiej sytuacji, że nikt nie ośmieli się spoufalać, traktować mnie jako swojego człowieka. Straszliwie zależy mi na niezależności, pojedynczości.

Od czasu do czasu robię jakieś grymasy - i to jest odczytywane jako bunt ${ }^{28}$.

Trudno, doprawdy, wyobrazić sobie większe uzależnienie od „państwa” (tu: od zapotrzebowania społecznego), niż ma to miejsce w przypadku poety manifestacyjnie osobnego. „Uzbrojony w niezawisłość wobec instytucji, mu si [on] [...] swoją niezawisłość nieustannie, poprzez sprzeciw wobec tejże samej instytucji, potwierdzać”29. Kiedy poczuł, że „głaszczą go za bardzo”, bo pisze „ładniutkie wiersze”, zaczęły nim kierować „niskie pobudki”. Mniej więcej w tym samym czasie wziął się do tworzenia czarnych kryminałów. W ramach tego najbardziej bodaj „ludowego” gatunku mógł kontynuować swoja „kryminalną, występną działalnośćc ${ }^{30}$. Kto popełnia zbrodnię, występuje przeciwko wspólnocie. Zarazem jednak zawsze jest przez nią warunkowany - bez wspólnoty nie byłoby zbrodni. „Brejkanie wszystkich ruli [...] możliwe jest tylko pod ich obecność”1. Banał, lecz im bardziej „Świetlicki” potęguje swoje uzależnienie od instytucji, tym szerzej, paradoksalnie, otwiera się dla niego przestrzeń suwerenności. „Podmiot kreaturalny” wie, że „Historia literatury wchłania wszystko” (Nie dla Jana Polkowskiego, R 584) i że „Można zanegować jej istnienie, wyśmiać ją, napluć na nią. Ale w ten sposób przedłuża się jej istnienie”32. I dlatego pisze: „Patrzę w oko smoka / i wzruszam ramionami” (Do Jana Polkowskiego, Z 61) - to jednak tylko kokieteria, bo obojętniejąc na spojrzenie smoka, zobojętniałby również na pisanie.

Jacek Gutorow notuje: „Poszukując momentu najbardziej własnego i autentycznego, Świetlicki odrzuca całą tradycję literacka, spuściznę kulturalną, osad ideologii, narracji, mitologii” ${ }^{3}$. Wręcz przeciwnie - on jest w tej tradycji cały, bez wyjątku. I dzięki temu zawsze, w każdym akcie twórczym, kreuje warunki możliwości wszystkiego ${ }^{34}$. Jak pisze Jakub Momro:

Marcin Świetlicki to poeta plastyczności świata. Oznacza to, że jego poezja jest szczególnego rodzaju intensywnościa języka, który tworzy rzeczywistość - tworzy, a nie odwzorowuje, przekształca, a nie przedstawia. Język tej poezji to siła metamorfozy, a nie komunikacji, poetyckiej epistemologii, a nie melancholijnej wsobności. [...]

$[\ldots]$

Wszyscy introwertyczni mężczyźni ida do wywiadu, s. 67, 68.

K. H off m a n n, Zombie. W zb.: Mistrz świata, s. 89.

Greckie „krima” (кріна) oznacza 'występek, naruszenie prawa, pogwałcenie tego, co zapisane', ale przede wszystkim szkodę uczynioną wspólnocie.

Hoff $\mathrm{m}$ a n n, loc. cit.

J. G u t o r o w, Niepodległość głosu. Szkice o poezji polskiej po 1968 roku. Kraków 2003, s. 112.

Ibidem, s. 110.

Jak zauważa P. Czapliński (Świat stoi przed nim potworem. O tomiku poetyckim Marcina Świetlickiego „Pieśni profana”. W: P. Czapliński, P. Śliwiński, Kontrapunkt. Rozmowy o ksiażkach. Poznań 1999, s. 123): „u Świetlickiego wiersz służy mówieniu o wszystkim, więc nadmiar nieważnych słów pogłębia rozpad, ale zarazem okazuje się, że właśnie poezja, pozwalająca wypowiedzieć wszystko, $z$ takiego "grzechu gadulstwa" czyni rację istnienia autora. Jeśli ktoś jest profanem, jeśli jest pomazańcem zwykłości, tedy całe jego życie jest grzechem - i w tym sensie całe nadaje się do wyznania. Co więcej, poeta-profan istnieje dopóty, dopóki gada”. 
Język tej twórczości zarazem otwiera możliwość przyjmowania przez język różnych form oraz wyłonienia się obrazów ze słownej magmy, jak i daje szansę poznawania i przekształcania świata poprzez te obrazy ${ }^{35}$.

Słowna magma, z jakiej zrobiony jest i w jakiej pracuje „Świetlicki”, rozbudza oczywistą ciekawość. Jak słusznie tym razem stwierdza Gutorow:

ma [ona] w sobie coś dziecinnego raczej niż naukowego. Nie o językoznawstwo czy semiotykę tutaj chodzi, lecz właśnie o dziecięcą ciekawość. Świetlicki rozbija słowa i utarte zwroty, przygląda się cząstkom języka, bawi się w fonetyka i morfologa, porównuje dźwięki, eksperymentuje z nowymi brzmieniami $^{36}$.

Lecz nie głód wiedzy jest tu najwyższą stawką, tylko - towarzysząca infantylnej dekompozycji - swobodna kreacja. Na rodzaj „pozytywnej destrukcji” zwrócił już zresztą uwagę Benjamin; w jego tekstach figura dziecięca pojawia się po to, by uhonorować barbarzyńcę, „którego celem jest odnowa świata”. Autor Berlińskiego dziecinstwa-

podkreśla dwa aspekty: kreacyjną i eksperymentatorsko-innowacyjną postawę dziecka, wyrażającą się w próbie konstruowania świata i nazywania go, oraz przestrzeń pierwotnego (magicznego) doświadczenia. Dziecko bowiem w zabawie rzeczami i słowami poszukuje ich nowego znaczenia i brzmienia, zniekształcając je $[\ldots]^{37}$.

Czy nie o tym jest Śmiertelność rzeczy martwych? Czytamy tam:

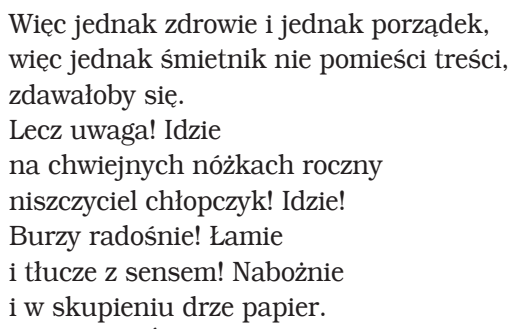

(Śmiertelność rzeczy martwych, T 181)

Niszczyciel chłopczyk, który jeszcze nie wie, nie domyśla się, że już zawsze będzie radośnie łamał i tłukł. Nabożnie drze papier, uświęcając twórczą destrukcję. Hańbi świętość sensu bezpośrednim i pełnym rozkoszy obcowaniem z materialnością tekstu. To robota kreatury.

\section{Mężczyzna}

W bruLionowej polemice Krzysztof Koehler „oskarżył” Świetlickiego o sianie ideologicznego o'haryzmu (tzn. stawianie na autentyzm wynikający $z$ afirmacji po-

B. Frydry czak, O zacieraniu śladów. Walter Benjamin i Fryderyk Nietzsche. „Nowa Krytyka” nr 15 (2003), s. 242-243. 
toczności i codzienności doświadczenia ludzkiego, personalną otwartość połączoną $z$ pewnego rodzaju ekshibicjonizmem) ${ }^{38}$. Następujace tezy Koehlera, mniej lub bardziej świadomie, w tej czy innej konfiguracji, krytycy będą powtarzać przez kolejne 20 lat:

Pragnie on [tj. Świetlicki] dokonać zabiegu zgoła magicznego: hipnotyzuje i wmawia, że jest wolny, autentyczny, poza wszelką konwencją, a przecież dla nas, czytelników, szamoce się choćby w sieci wersów i to, co miało byś autentyczne i wolne, jest - bo taka jest poezja - sztuczne i zniewolone. Marcinowi Świetlickiemu wydaje się, że w ramach konwencji i dzięki konwencji zdoła tę konwencję rozbić w puch i stanąc przed nami nagi, w świetle prawdy ${ }^{39}$.

W tej dyskursywnej ciekawostce najbardziej interesujace okazuje się - rzecz jasna - to, czego w niej nie ma. Koehler przeocza bowiem fakt, iż ekshibicjonizm Franka O’Hary polegał m.in. na „Znacznej jak na ówczesne zwyczaje otwartości w kwestii nienormatywnej orientacji seksualnej" ${ }^{40}$. Na ten paradoks zwraca uwage Jan Potkański pisząc, że poezja „bruLionu”, a zwłaszcza twórczość samego Świetlickiego - przynajmniej z wierzchu -

jest [...] ostentacyjnie „męska” i „heteroseksualna” - tak silnie, że aż często zdominowana przez „homosocjalność”, nieseksualne (wręcz antyseksualne) związki mężczyzn, jak „męska przyjaźń” [...]. Relacje mistrz-uczeń między O'Harą i o'harystami, otwartym gejem i „silnymi mężczyznami” przywiązanymi do swej heteroseksualności, okazują się zatem równie dwuznaczne jak „Związek” Jerzego Andrzejewskiego z Markiem Hłaską ${ }^{41}$.

Temat „homospołecznej wyobraźni poetyckiej” Świetlickiego podejmuje przede wszystkim Błażej Warkocki w szkicu Jedna narzeczona dla siedmiu poetów (o męskim pożadaniu homospołecznym, trójkatach i poezji $w$ „Niskich pobudkach”). Badacz stawia tezę, że o heteroseksualnej tożsamości podmiotu Niskich pobudek decyduje trójkątne pożądanie. „Między nami mężczyznami”, znanymi z imienia i nazwiska, rodzi się bliska relacja zapośredniczona przez kobiece - anonimowe medium. Kobieta istnieje tylko teoretycznie, jako abstrakcja lub funkcja społeczna: np. w utworze Wola ludu (N 454): „Krakowska narzeczona S. Sierakowskiego”. Warkocki, analizując pobieżnie Wiersz nie tylko dla Pasewicza oraz Wiersz doraźny, dochodzi do wniosku, iż „homospołeczne kontinuum, które zarysowuje poeta [...], jest dyscyplinowane przez homofobię" ${ }^{2}$. I w konsekwencji to „wspólna narzeczona” (śmierć, poezja) stanowi konieczny łącznik, a zarazem bufor zapewniający bezpieczeństwo w męskich relacjach. Zawartość tych utworów -

K. Ko ehler, O’haryzm. „bruLion” nr 14/15 (1990).

Ibidem, s. 142.

J. P ot k a ń s k i, Epoka spojrzenia. Literatura i społeczeństwo nowego kapitalizmu. Warszawa 2014, s. 48. Postać O'Hary w tekście Ko ehlera się nie pojawia, być może została jednak delikatnie zasugerowana (op. cit., s. 142): „czy rzeczywiście jest sens wmawiać swemu rozmówcy (jeśli nie jest nim ktoś z rodziny ani kochanek, ani dziewczyna) [...] bezwarunkową, autentyczną historię swych przewag i upadków" (podkreśl. D. M).

Potkański, loc. cit.

B. Wa rk o cki, Jedna narzeczona dla siedmiu poetów (o męskim pożądaniu homospołecznym, trójkatach i poezji $w$ „Niskich pobudkach”). W zb.: Pierwsza połowa Marcina. Szkice o twórczości Marcina Świetlickiego. Red. E. Kle dzi k, J. Ros zak. Poznań 2012, s. 95. 
To pożądanie homospołeczne w stanie czystym. Bo to o nie chodzi przede wszystkim. I o mężczyzn. Nie o poezję, nie o śmierć, nie o narzeczoną. O bardzo doczesne, silne związki z mężczyznami ${ }^{43}$.

Świetlicki pośrednio „odpowiedział” na tę diagnozę Warkockiego (avant la lettre) już w 1998 roku $^{44}$. W wierszu Tobót zwierzył się ze swoich homospołecznych dylematów kobiecie, którą poznaliśmy tym razem $z$ imienia:

Popatrz, Moniko. Ten wiersz zaludniają

głównie mężczyźni. Takie heroiczne

czasy nastały. [...]

(Tobót, P 272)

Autoironiczne gry z męskością i mężczyznami to zresztą element konsekwentnej strategii twórczej Świetlickiego. Wychwycił tę kwestię Maliszewski:

Osobowość to doprawdy zagadkowa. Pojawił się ktoś taki w polskiej poezji pod koniec XX wieku - ze swą zniewalającą zniewieściałością, uroczym sposobem zawracania głowy, zwracania powszechnej uwagi na swoje drobne wzloty, prywatne upadki ${ }^{45}$.

Paradoksalnie - jedynym prawdziwie męskim pierwiastkiem w tej twórczości są niekontrolowane, cielesne konwulsje, „niemęskie” ruchy i gesty (jak najdalsze od „maczoidalnych” męskich póz, które lubią przed sobą i przed innymi odgrywać aktorzy homospołecznego spektaklu) targające Świetlickim zarówno na scenie koncertowej, jak i „na scenie” pisma.

Warkocki pisze o „Świetlickim” i „triangulacji pragnienia”, korzystając z osiagnięć teoretycznych Eve Kosovsky Sedgwick, i jest w tym przekonujący. Ale na „Świetlickiego" zmagania $z$ męskością można by równie dobrze popatrzeć przez pryzmat psychoanalizy Sigmunda Freuda. Idąc tym tropem, nietrudno byłoby pokazać (będąc przy tym niewiele mniej przekonującym), że podmiot tak naprawdę $\mathrm{w}$ najmniejszym stopniu nie jest zainteresowany męską rywalizacją $\mathrm{z}$ takim czy innym „S. Sierakowskim”. I że to jego narzeczonej pragnie (oraz analogicznie: narzeczonej któregoś z byłych kolegów) - i że to ona, z racji „przynależności” do innego mężczyzny, wydaje się „Świetlickiemu” autentycznie pociagająca. Freud w następujący sposób wyłożył tę zasadę seksualnego „prawa własności”, którą rzekomo kierują się mężczyźni w wyborze obiektu uczuć:

można [ją nazwać warunkiem „poszkodowanej osoby trzeciej”; treść tego warunku sprowadza się do tego, że dany mężczyzna nigdy nie obiera za obiekt miłosny kobiety jeszcze wolnej, a zatem dziewczyny czy samodzielnej niewiasty, lecz zwraca się wyłącznie ku takiej kobiecie, do której prawa własności może wysuwać inny mężczyzna - małżonek, narzeczony, przyjaciel. [...] dana kobieta zrazu może być w ogóodpowiedział Warkockiemu bezpośrednio i w sposób „najniższy” z możliwych - wyeksponowany, komediowy prymitywizm łączy się tu z polityczną perwersją - w wierszach Gejskie granie („szanuj / ich faszystowski gender, kibicuj ich wszystkim / projektom, [...] / [...] / [...] zabij to uparte dziecko. / Asymiluj sie”, s. 10) czy Czarna niedziela („Dzień nieprzyjemny jest jak Kinga Dunin. / Nic tylko schować się i skuczeć. / Nic tylko niepoprawnie używać wyrażeń / przy swojej suce [...]”, s. 71).

Ibidem, s. 96.

Również w późniejszym tomie Delta Dietla. Wiersze 2013-2015 (Kraków 2015) M. Św i etlick i Maliszewski, op. cit., s. 63. 
le niezauważona czy wręcz wzgardzona, jeśli nie należy do nikogo innego, podczas gdy staje się przedmiotem zakochania, gdy tylko wejdzie we wspomniane tu stosunki $z$ innym mężczyzną ${ }^{46}$.

Podążając dalej za tym - całkowicie już przebrzmiałym - przeświadczeniem Freuda, trzeba by sformułować ostateczny wniosek, że mówiąc „Sierakowski”, Świetlicki chce powiedzieć „ojciec”. Według dojrzewającego chłopca matka „należy” do ojca i owa przynależność stanowi nieodłączny składnik bycia matki jako matki (a co za tym idzie, obiektu jako obiektu pożądania). $Z$ biegiem czasu schemat ten przenosi się na inne - pożądane - kobiety. Ale żeby „zaiskrzyło”, niezbędne jest medium w postaci ojca. Stąd właśnie „Sierakowski” i wszyscy zaludniający twórczość Świetlickiego mężczyźni: są oni przeszkodą pozwalającą bohaterowi pragnąć. W tym wariancie lekturowym nie chodziłoby zatem o to, że kobieta daje pretekst do męskich schadzek, lecz przeciwnie - męskie związki są konieczne, by zbliżyć się do kobiety i nauczyć się jej pragnąć.

Jeszcze raz więc sprawdza się zasada, która głośno sformułował Krzysztof Hoffmann:

każdy ma takiego Świetlickiego, jakiego sobie wyczytał. To poeta konsekwentny, ale już nie radykalnie spójny, albo jednowykładniowy, tyleż podsuwający proste recepty na tę twórczość, ile zaraz je palący $[\ldots]^{47}$.

Skoro ta pierwsza uwaga odnosi się do absolutnie wszystkiego, co tylko nadaje się do czytania, to ujmijmy ją inaczej: każdy ma takiego Świetlickiego, na jakiego sobie zasłużył. Dla Świetlickiego rzeczywistość jest plastyczna, a język ją dowolnie, choć nie bez bólu i trudu, formuje (nie zaś reprezentuje ${ }^{48}$. Dlatego kreatura z powodzeniem może odgrywać rolę zarówno miłośnika mężczyzn, skrywającego swe uczucia pod maską homofobii, jak i neurotycznego młodzieńca, pragnącego kobiety tylko wtedy, gdy pragnie jej ktoś inny, a także - od niedawna - zakochanego obserwatora, opiewającego uroki życia „Z nią” (co da się dostrzec np. w wierszu O. z tomiku Jeden).

Być może dlatego „samcza twórczość” Świetlickiego nie doczekała się jeszcze kompleksowego genderowego (ani psychoanalitycznego itp.) opracowania - zbyt łatwo takiemu opracowaniu się poddaje. Sam poeta również dość często naprowadza zainteresowanych na trop. Choćby wtedy, gdy w pewnym wywiadzie zdobywa się na taką definicję:

Męskość polega na skrótowości. - Męskość jako wartość? - A dlaczego nie? Jakichś wartości trzeba się trzymać. Męskość to pewien styl wypowiedzi, styl myślenia. Oczywiście, główną wartościa jest wielka sztuka, a ta bywa i rozgadana, i skrótowa ${ }^{49}$.

A więc, $z$ jednej strony, męskość „polega na skrótowości” i w tym tkwi jej waru mężczyzny. W: Życie seksualne. Przeł. R. Res z ke. Warszawa 2009, s. 169-170.

47 Hoffma n n, op. cit., s. 84.

48 Zob. Mom ro, op. cit., s. 242.

49 Jestem plagiatorem. Z M. Świetlickim rozmawia M. S a w i c ka - D a n i e la k. „Uważam Rze” 2011, nr 22. 
tość, ale z drugiej - wartość stanowi sztuka: ta skrótowa oraz ta rozgadana. Charakterystyczny i programowy brak spójności w obrębie kilkuzdaniowej wypowiedzi. A podmiot? „Porusza się pomiędzy”.

Nie ma wszakże wątpliwości, że zarówno seksualność, różnica seksualna, jak i pozycja mężczyzny w obrębie tej różnicy jest dla Świetlickiego czymś więcej niż tylko kolejnym zagadnieniem do uplastycznienia. Widać to doskonale $\mathrm{w}$ wierszu Upat $w$ szpitalu:

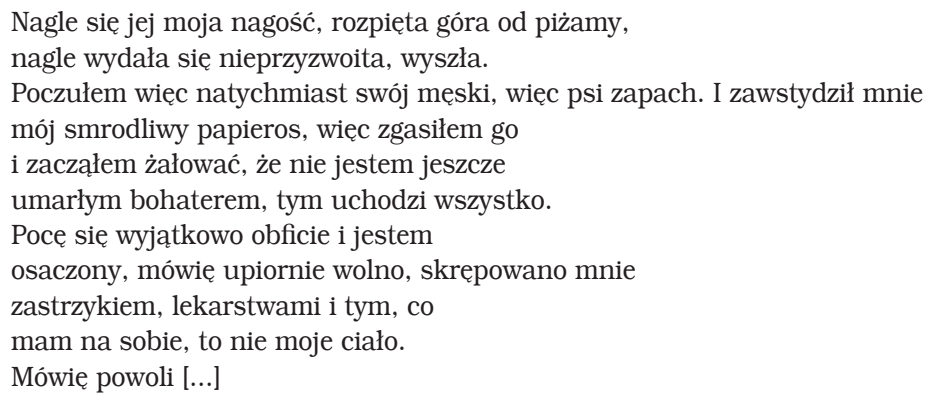

(Upat w szpitalu, Z 27)

Męskość realna, nie jako literacka fikcja, dochodzi do głosu w momentach kryzysowych, w których ciało daje o sobie znać, gdy odmawia posłuszeństwa. Męskość okazuje się wtedy radykalną obcością - wyobcowana z siebie, z symboliki i wyobrażeń na swój temat („to nie moje ciało”). Na męskość nie da się patrzeć, nie sposób jej wąchać. Męskość to „przeżyty” wstyd.

Więc to nie do końca tak wygląda, jak twierdzi Magdalena Bednarek, że to, „co w sytuacji miłosnej byłoby męskie (i pozytywne), w szpitalu okazuje się nieprzyzwoite, widząc cielesną mięsność, "rozpięta górę od piżamy" [...], ona odchodzi [...]" ${ }^{50}$. Tutaj ujawnia się fakt, że nie istnieje coś takiego jak „sytuacja miłosna” (w której znalazłaby swoje miejsce jakaś pozytywna męskość). Następuje nagłe olśnienie także ze względu na wstręt, jaki czuje kobieta - jeśli kwestia dotyczy męskiego ciała, to nagle cały świat staje się szpitalem, w którym panuje skrępowanie, obcość i „nieswojość”. Nie ma innej, bardziej intymnej przestrzeni, nie ma dogodniejszych warunków, w których męskość jako taka mogłaby się pomyślnie realizować (ależ sa - powie Świetlicki - można je znaleźć we wszystkich kliszach na temat „prawdziwej męskości”, np. tych z Humphreyem Bogartem w roli głównej: ich podstawowym zadaniem jest ochrona przed wstydliwą traumą). Męskość wydaje się z gruntu nieprzyzwoita, „psia” ${ }^{1}$, nie przystaje do wyobrażeń zarówno innych (ona „wyszła”), jak i podmiotu („to nie moje ciało”). Ciało wymyka się mężczyźnie, jest „wobec niego wrogie. [...] Obcość - jego własna obcość - stała się jego panem" ${ }^{2}$. Pies nie ma $w$ tej sprawie nic do gadania, jest ostatecznie zobowiązany:

To nie jest wolność, bo to jest konieczność.

To nie jest wybór, to jest nakaz. Lecz to

M. B e d n a r e k, Kobieta, której nie ma. W zb.: Mistrz świata, s. 205.

„Psi zapach” to ewidentne nawiazanie do „mysiego zapachu” z wiersza Czyści S. Grochowiaka.

B en ja min, Franz Kafka, s. 242. 
Wymachiwanie ogonem nieograniczone

Jest. [... $]^{53}$

Dlaczego podmiot $z$ wiersza Upał $w$ szpitalu żałuje, że nie jest umarly? Bo jako taki, czyli umocowany w porządku symbolicznym „Bogart”, dysponowałby mnogością lekkomyślnych i nieważnych słów, które mogłyby w końcu odcieleśnić ów druzgocący obraz (,umarłym [...] uchodzi wszystko”, łącznie z seksualnym napięciem). „Smrodliwa” męskość to zaledwie chwila, ale trwając w niej, podmiot mówi „upiornie wolno" - osaczony i skrępowany, nieswój, lecz tylko w tym jednym momencie autentycznie wolny. „Mówię powoli” - zgodnie $z$ wolą. Reakcją na ów traumatyczny wgląd w „istotę" męskości - bycie, które okazuje się nie do zniesienia, ujawnia się tylko poprzez klęskę - jest sublimacja, zagadanie materii, często u Świetlickiego realizujące się poprzez prowokowanie konfliktu $z$ wrogiem urojonym, kobietą. Damsko-męska sztampa ratuje podmiot przed zatraceniem się w materii pisma (przed „nabożnym darciem papieru”).

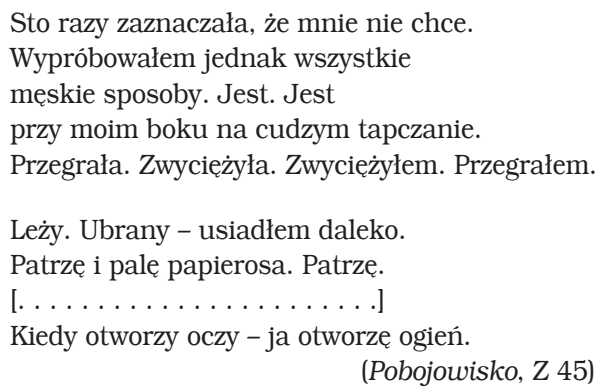

Sugestia wydaje się dość jasna i konserwatywna - seksualność, różnica seksualna, ma charakter wyłącznie antagonistyczny. Nie istnieje żadna możliwość porozumienia. Papieros zamienia się w broń w każdej chwili gotową do strzału. Potencja znajduje się na swoim miejscu, a klisza goni kliszę (jak w Pogo: „mam w sobie gorący / detal, teraz cię muszę znaleźć”, W 148). Związek seksualny nawet nie tyle nie istnieje, ile jest przez te chwilowe zbliżenia-rywalizacje jeszcze bardziej rozluźniany. Mężczyzna i kobieta są dla siebie jak pies („teraz chcę być twoim psem” 〈I Wanna Be Your Dog, W 163)) i kot („tak to kotku wygląda / i tak się to kończy” 〈Trzecia połowa, T 203〉).

W muzycznej wersji wiersza Palenie Świetlicki melorecytuje: „Bo to jest, bracie, wojna, wojna palących z niepalącymi. Odwieczna dychotomia, jak Legia i Polonia, jak Wisła i Cracovia, jak Staś i Nel"54. Wojna, przez poetę metonimicznie zredukowana do awantury o papierosa, ma charakter stricte seksualny. To zastanawia, bo w poetyckim opracowaniu różnicy seksualnej widać tu ewidentny nadmiar. Rozpoznanie swojej seksualności czy ustosunkowanie się do niej stanowi warunek wejścia w porządek symboliczny (mówi ona albo on - ono co najwyżej wydaje z siebie głos). Tutaj owa symbolika podniesiona zostaje do drugiej potęgi - seksualność

M. Św i e tli c ki, Psie obowiazki. W: Delta Dietla, s. 72

Palenie na płycie Sromota zespołu Świetliki. W wersji drukowanej nie ma cytowanego fragmentu (zob. Cz 307). 
jako „odwieczna dychotomia”, wyrażająca się w pełni dopiero w języku symboli (Staś i Nel). „Świetlicki” nawet nie stara się ukrywać, że czuje się stroną w tym „odwiecznym" konflikcie, że jest emocjonalnie, a nawet somatycznie zaangażowany w sprawę swojego małego papierosa:

Mój mały przyjacielu, papierosie.

Spędziłem z tobą więcej czasu niż z kimkolwiek.

Niszczymy się nawzajem, czule

oddani sobie.

(Palenie, $\mathrm{Cz}$ 307)

Jak każda wojna, także wojna seksualna druzgoce wroga (niepalących, czyli - po prostu - kobiecość) oraz sprawia, iż „wypala się” przyjaciel, protagonista. I staje się wrogi sam sobie. Mimo wszystko jednak - zapowiada walkę do końca:

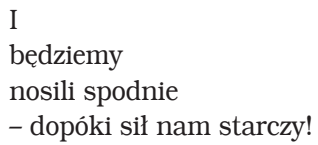

(Obiecywanie, $\mathrm{Cz} 306$ )

Zdecydowane, wielkie, samotne „I” w nagłosie, „Wzwód wymierzony w ciemność” (Małżowina, P 267), nie pozostawia wątpliwości, że ciągle jeszcze ma o co walczyć, że bohater jest samotny i „umarły - ale nie uwiędły” (P 267). „Nim będzie śmieszny i stary”, da radę „wyjść” o własnych siłach i na własnych warunkach, nie pogubi się (P 267). Takie samo sterczące „I” pojawia się, nawet w bardziej jednoznacznym kontekście, w wierszu zaczynającym się od słów „Pierwszy raz się zbudziłam spokojna”. To bodaj jedyny utwór, w którym „Świetlicki” mówi w rodzaju żeńskim. Ale i tam gramatyczna oraz graficznie odzwierciedlona erekcja wdziera się i zakłóca spokój.

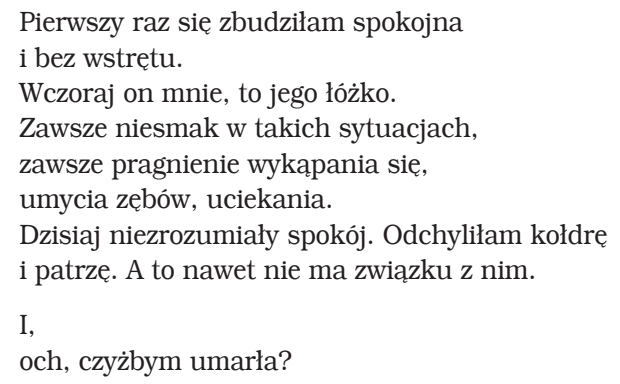

(Pierwszy raz się zbudziłam spokojna..., T 187)

Chwilowe zawieszenie broni działa na bohaterkę kojąco, lecz tylko do czasu, gdy materię tekstu rozdziera wielkie „I” - łącznik, który dzieli, twardość, która zmiękcza ${ }^{55}$ (doprowadza do śmierci albo do orgazmu: „och, czyżbym umarła?”). Po raz kolejny męskość i zakwestionowanie męskości okazują się jednym i tym samym.

Kiedy w 2006 roku Świetlicki rozpoczyna swój cykl kryminalny, jego bohater legitymuje się następującym „dowodem tożsamości”. Imię: brak. Nazwisko: brak. 
Pseudonim: Mistrz. Wiek: 44 (oczywiście!). Najbliższa rodzina: Suka (suka). Praca: bezrobotny. Wykonywane zajęcie: pijak, atrakcja turystyczna, „szalenie niekonwencjonalny, szalenie prywatny detektyw"56. Znaki szczególne: nie posiada „dowodu osobistego, pracy, paszportu, [...] telefonu, komputera, samochodu, karty do bankomatu, pretensji do bycia zdrowym, pogodnym i zapobiegliwym" 57 . Skrajnie niezainteresowany tym, co mówią o nim inni, goraczkowo pragnie usłyszeć, co mają o nim do powiedzenia. „Pijaczyna. Nic nie robi. Skończył się. Spuchł, posiwiał i utył"58. „Żyje w przeszłości. Nie zadaje niepotrzebnych pytań”59. Nieakceptowany i odizolowany od otoczenia, bez znajomości ogólnie przyjętych norm zachowania, nadal pozostaje $\mathrm{w}$ centrum wydarzeń. To najważniejszy punkt miasta i totalny wyrodek w jednej osobie:

Mimo że nie jest nigdzie zameldowany, mimo że nie ma żadnych dokumentów, mimo że tak naprawdę nie istnieje, niemal codziennie znajduja go, pokazują mu swoje ordynarne pomysły, przymuszają go do słuchania ich muzyki, oglądania ich dzieł sztuki. Dają mu istnienie, wpychając jednocześnie w błoto ${ }^{60}$.

Najpełniej wszakże Świetlicki przedstawia bohatera na ostatniej stronie okładki swojego pierwszego kryminału:

dawny gwiazdor kina dziecięcego, mężczyzna przegrany, detektyw z przypadku. Nazywają go mistrzem. Nie posiada dowodu osobistego, komórki, konta bankowego ani prawa jazdy. Mówią na mieście, że utył, spuchł, posiwiał. I nagle, zupełnie nieoczekiwanie, w prywatność jego nikomu niepotrzebnego istnienia wkracza zbrodnia ${ }^{61}$.

„Mężczyzna przegrany” - ta identyfikacja wydaje się w swej dwuznaczności najbardziej wymowna. $Z$ jednej strony, to ten, który doznał porażki, został pokonany i pogodził się z losem, $z$ drugiej - ten, który wciąż jest w grze. Ciagle może próbować od nowa, bo mimo że jeszcze nie zaczął grać, już od razu poniósł fiasko. I to czasowe napięcie, ów stan zawieszenia w obrębie porażki (między ,jeszcze nie” a ,już tak”), warunkującej wszelako wejście do gry (i w konsekwencji możliwość zmiany jej zasad) cechuje ową prozatorską kreaturę. „Przegranie” odnosi się jednak - niemal tautologicznie - do mężczyzny. On nigdy przecież nie spełnia oczekiwań. Nie dorasta. Mężczyzna to ktoś, kto zawodzi. Oto co mówi na ten temat psychoanalityk: „chciałbym zaproponować, byśmy postarali się zrozumieć "falliczny" jako 'zawodny', by usłyszeć faillir ('zawieść) w fallusie"62. Fallus, tak jak mężczyzna, to przede wszystkim coś, co rozczarowuje, co prędzej czy później trzeba odrzucić albo przekroczyć.

Mistrz, wyrzutek manifestujący i ceniący swoją niepotrzebność, dużo uwagi poświęca temu, co ludzie o nim mówią. Zazwyczaj mówią źle, wyrażają rozczarowanie. Więc kiedy tylko dwie dziewczyny przy stoliku obok zaczynają rozmowe o kondycji polskiego mężczyzny, mistrz natychmiast nadstawia ucha:

M. Świetlicki, Dwanaście. Kraków 2006, s. 137. Zob. też s. 7.

Ibidem, s. 5.

Ibidem, s. 32.

M. Świetlicki, Trzynaście. Kraków 2007, s. 6.

Świetlicki, Dwanaście, s. 190.

Ibidem, s. 4 okładki.

B. Fink, Wiedza i jouissance. Przeł. J. J aj s z c zo k. „Er(r)go” 2008, nr 1, s. 113. 
- A popatrz [...] na tego, siwego, tu przy stoliku obok... Nie wnikam, kim on jest, nic mnie to nie obchodzi, brzydzę się nim, ale jakby tak na moment się na nim skupić, to jasne dla mnie jest to, że spokojnie może zostać uznany za postać mówiącą nieco o kondycji polskich mężczyzn. Stanowi ka rykaturalny wizerunek kolejnej lost generation wiecznych chłopców przeistoczonych niepostrzeżenie w przedwczesnych starców. Zapity, apolityczny, zbuntowany przeciw wszystkiemu, czyli bliżej nie wiadomo czemu, przeżywa relacje społeczne i uczuciowe w sposób skrajnie niedojrzały. Jest raczej nieszkodliwy, bo przecież niszczy tylko samego siebie. Upozowany, wycofany, szyderczy i depresyjny. Chory na alkoholizm, nadwrażliwy i kompletnie zobojętniały. Dekadent i nikotynista. Postrzegam go jako postać tragiczną i groteskową, antytezę dziarskiego, wszechpolskiego chłopca i uosobienie obywatelskiej niemocy wolnościowego kontestatora $z$ lat osiemdziesiątych. Nie jest ani prawicowy, ani lewicowy. Nie rozumie świata. Nie dorósł, a zdziadział ${ }^{63}$.

Diagnoza jest dość łatwa do przewidzenia i mistrz jako mężczyzna przegrany musi się w niej rozpoznać. Choć na jej podstawie można się pokusić o wnioski bardziej ogólne. Po pierwsze, mowa jest o karykaturze. A mężczyzna to już zawsze tylko karykatura mężczyzny, mężczyzna nieadekwatny, nie-mężczyzna ${ }^{64}$. Po drugie, w dyskursie pada termin „lost generation”, pierwotnie odnoszacy się do pisarzy uwikłanych $\mathrm{w}$ doświadczenie pierwszej wojny światowej. Ale mistrz też ma swoje kombatanckie doświadczenie, też należy do straconego pokolenia, ma własną męsko-damską - wojnę. Wojnę, którą musiał przegrać. Tak jak w wierszu Przeproś (P 235):

Ożywiam się tylko wtedy, gdy myślę o sobie w tobie. (Przeproś!)

$[\ldots \ldots \ldots \ldots . \ldots]$

Kiedyś było inaczej, kiedyś było lepiej

- przed moją wielką wojną, na której poległem.

Po trzecie, ostrze dziewczęcej krytyki wymierzone zostało również w upozowanego buntownika. Infantylnego i nieszkodliwego, bo politycznie obojętnego. Reakcja bohatera na obrzydzenie rozmawiających jest znamienna: „Jezu... - mruczy mistrz. - Czy ona to o mnie mówi?"65 Nic dziwnego, że w kontekście usankcjonowanego buntu bohater wzywa na świadka akurat Jezusa, jedną z najwcześniejszych kreatur Świetlickiego. Wiersz Apokryf (Z 13) warto przytoczyć w całości:

\footnotetext{
Maleńki Jezus był nieznośnym dzieckiem.

Od razu było widać, że nie całkiem jest stąd.

Stada staruszek rozprawiały o nim,

wykonując ówczesne zabobonne znaki.

To dziecko miało nienormalną pamięć, pamiętało dokładnie cały gwiezdny porządek i stosowało go na swój męczący i niezrozumiały sposób.

Wpadał z patykiem $\mathrm{w}$ dłoni między rówieśników organizując rewolucje
}

Świetlicki, Trzynaście, s. 170. Podkreśl. D. M.

Męskość jest „praktyką niestosowności: nigdy nie jest się dość mężczyzną, a skoro nie jest się mężczyzną w stopniu dostatecznym, jest się niebezpiecznie nie-męż c zy zną" (F. La Cecla, Szorstkim być. Antropologia mężczyzny. Przeł. H. Se r k ow s ka. Warszawa 2014, s. 57).

Świetlicki, Trzynaście, s. 170. 
albo zamieniał złośliwe staruszki

w ptaki i muchy.

Rodzice często brali go na stronę

i przyglądali mu się $z$ niepokojem,

wówczas podnosił ostrzegawczo palec

i speszeni wracali do swych obowiązków.

Teraz wisi na ścianach pomiędzy kwiatami

i ponad tapczanami licealistek,

został wchłonięty przez te same staruszki

i mężczyźni w sukienkach używają go.

Ale to, jak się zdaje, zbyt go nie obchodzi.

On siedzi na krawędzi, stuka patykiem o patyk.

Gwiazda spada, następna

wznosi się.

Oto karykatura rewolucjonisty. Nieznośny, męczący chłopiec z patykiem w ręku. Nieustannie grożący systemowi palcem, ale w całości przez niego połknięty. Lecz tylko dzięki temu może od czasu do czasu stać się instancją wypaczającą funkcjonowanie owego systemu, samą w sobie nieobecną, nawet nieistniejącą, ujawniającą się jedynie poprzez efekty swoich działań, zmieniająca „, bieg przyciaganych zdan”, fragmentów narracji ${ }^{66}$. Kreatura to właśnie tego typu instancja - nie istnieje, ale działa i wpływa na warunki istnienia. $Z$ mężczyzna jest odwrotnie - istnieje (aż za bardzo), tylko nie działa. Świetlickiemu udało się połączyć ogień z wodą - pod pozorem konserwatywnej męskości przemyca on do kanonu (także tego szkolnego) kobiecą, wywrotowa kreaturę ${ }^{67}$. A jednocześnie chroni „się” przed naporem cielesnego, wstydliwego i zawsze nieswojego bycia mężczyzną.

Abstract

DAWID MATUSZEK University of Silesia, Katowice

CREATURE - ŚWIETLICKI UNDER THE PRETENCE OF MASCULINITY

Marcin Świetlicki identifies the speaking subject of his creativity as a "metrical creature." The author of the article juxtaposes this poetic insight with Benjamin's concept of creation (die Kreatur) and on that basis builds a theory of subject which emerges from Świetlicki's writing.

The creature is a subject and a litter, creator and creation within one "speaking person." Its creative work does not base on avant-garde formation of everything anew but rather on converting and reshaping the present situation, to date literary reality. Creature is "incomplete": it belongs to the collection of "literature" but at the same time incompletely falls into its scope thus distorting it. In this sense and according to Jacques Lacan's formulas of sexuality, creature is a woman.

The author proves that the demonstrative "masculinity" of Świetlicki's writing is only a staffage due to which a writer may tactfully, in woman-like manner, change the rules of the play from the inside, and concurrently protect himself against the pressure of bodily and shameful - for constantly beyond himself - being a male.

67 Symptomy tego dostrzegł już Malis zew s ki (op. cit., s. 67): „Wiersz staje się auto-karykaturą, auto-drwiną, a realnym celem [jest] pokazanie swego skomplikowania, rozdarcia, głębi, a także: [...] kobiecości”. 